\title{
Self-Efficacy of Elementary Teachers and their Attitude towards Practices of Classroom
}

\author{
Management \\ * Dr. Fouzia Ajmal (Corresponding Author) \\ ** Zaib u Nisa \\ *** Prof. Dr. N. B. Jumani
}

\begin{abstract}
This study aimed to investigate the self-efficacy of elementary teachers and their attitude towards practices of classroom management at the elementary level in Mansehra. This study was descriptive. The population of the study consisted of all elementary school teachers and students (female and male) in district Mansehra. The respondents were selected by the stratified random sampling technique. Three hundred and ten teachers at elementary schools (male and female) were selected as a sample from the one thousand and sixty-three elementary teachers. The questionnaires were developed by the researchers to investigate the self-efficacy and attitude towards practices of their classroom management. The researchers used a five-point scale (always, often, never, rarely sometimes, and never) for data collection, and data were analyzed by descriptive statistics (mean, percentage, frequency), inferential statistics (chi-square) and p-value. The p-value shows that female elementary teachers' self-efficacy and attitude towards their practices in classroom management is significant than male elementary teachers. This study recommended that male teachers' self-efficacy enhanced their ability along with advanced teaching methods for educational activities.
\end{abstract}

Keywords: Elementary Teachers' Self-efficacy, Teachers' Attitude, Practices of Management, Management in the Classroom

\section{Introduction}

Self-efficacy is an important factor in an individual's motivation and this concept of self-efficacy was introduced by Bandura in 1994. The important role in the human behavioursis self-efficacy. The atmosphere that involves a generative ability and organized the innumerable purposes is combined developments of action into behaviors, social, and cognitive are called Efficacy (Peleg \& Idan-Biton, 2018). Individual's beliefs in their particular skills to achieve a certain task with preferred outcomes have been defined as self-efficacy (Ansonga, Eisensmith, Okumu, \& Chowa, 2019). Bandura (1994) suggested that self-efficacy covered many situations, self-efficacy is different in different people some individuals have a solid sense of self-efficacy and others have not. They solved and resolved many difficult situations and tasks due to self-efficacy (Garvis \& Pendergast, 2016). If students ignore the rules of the classroom and remain off duty during coaching so it was called low self-efficacy teachers (Abu-Tineh, Khasawneh, \& Khalaileh, 2011). The effective classroom management policy created by the teachers having high self-efficacy, they are planning phase during the delivery mode, implemented the effective methods and they keep well managed (Rashid, Khalid, \& Salfi, 2014).

Teachers have high creativity and high self-efficacy they can solve problems; a High level of self-efficacy believes teachers play a critical role to promote creativity in research and teaching (Chang, 2019). This study suggested that high self-efficacy teachers exhibit an ability to manage a classroom, increase student academic achievement, and create an atmosphere where learning can take place: their skills have a positive impact on classroom students, otherwise low self-efficacy teachers are considered -it on of the most stressful job; they are less likely this profession and leave the profession (Patterson \& Farmer, 2018). Students learning outcomes, academic adjustment, and achievement associated with teachers' self-efficacy, and provide support and positive classroom management atmosphere, teachers' attitude and self-efficacy beliefs described teachers' confidence,

\footnotetext{
* Department of Education, International Islamic University Islamabad Email: fouzia.ajmal@iiu.edu.pk

** Hazara University, Mansehra Email: nisa.rasheed17@gmail.com

*** International Islamic University Islamabad Email: nb.jumani@iiu.edu.pk
} 
training, and experience in working with students in the classroom (Lee, Cheung, \& Chen, 2019). Students' understanding, attention, and satisfaction in the classroom are significant interactions of elementary teachers' self-efficacy, and student's development and motivation depend on it and creativeness (Nassir \& Yusob, 2019). Students have a positive impact on their learning, motivated to manage study timing, and promoted collaborative work in a flattering management classroom environment (Toni Dobinson, 2019). This research has specified dimensions to be explored remaining focused on "Self-efficacy of elementary teachers' and their "attitude towards practices of classroom management".

\section{Literature Review \\ Self-efficacy}

The social cognitive theory $(1986,1989)$ suggested by Bandura, the self-referent supposed of action is modest between knowledge and action. He described that people assessed their own experiences and self-reflection through the thought process. He viewed individuals as self-reflecting, self-organizing, self-regulating, and proactive rather than as reactive organisms He argued that the capabilities and beliefs of the people better predicted by their behaviors, rather than people are capable of accomplishing. The people have knowledge and skill; it can be assumed the people self-efficacy perceptions are determined (Garvis \& Pendergast, 2016). Self-efficacy refers that individuals can control their motivation, behavior, and social environment (Chen, 2018). Self-efficacy developed the individual's behavior and motivations and indicated the creativity in the work process. Creativity, style working, generating idea, independence, ambiguity tolerance, and concentration involved to develop the self-efficacy of individuals beliefs. Positive self-efficacy beliefs are creative thinking strategies and regards products creative external assessment negativity beliefs countering (Chang, 2019).

\section{High and Low Self-efficacy}

Confidence to perform a professional behavior or succeed in a profession is created by high selfefficacy. The physiologic, experience of vicarious, persuasion verbal, and mastery personal feedback are attained by high self-efficacy. High self-efficacy individual's beliefs obtained the support of the social network, solved difficulties area of problems, created emotional regulation, and constructed confidence and effective environment (Szanton, 2019). Self-confidence, self-concept, self-esteem, and stability are related to the concept of high self-efficacy and it is formed through experiences and interpretation of the atmosphere, people made interaction with the social and economic culture. High self-efficacy is based on past experiences, feelings to relate to a future task and have not tightly bound by cultural norms, and it look forward towards the future. High self-efficacy asked the question "how well can I do at this", the high self-efficacy means that teachers and students work hard with full energy towards their goals (Andrew, 2019). Individuals who have low self-efficacy shown their behavior through emotional and physical stress, emotional conditions, and tired body conditions, fear to work, and not struggled for future show the low self-efficacy in people (Bakker, 2016).

\section{Self-efficacy Elementary Teachers' Classroom Management Practices}

The' self-efficacy elementary teachers' beliefs that currently function and judgments affected by their teaching and process in the classroom, they have skilled to introduce the competency of activity. When teachers put an attempt to become more acquainted with every learner, they get more out of their experience too. At the point when you advise children to quit talking and return to work however you don't finish, you are viably revealing to them it doesn't make a difference that much. Teachers may create plans that work for managing classes and provoke the interest of the learners. Teachers' self-efficacy has an important role and a positive impact on the learning and development of the students. Classroom teachers are plan and implemented developmentally appropriate practices in the management of the classroom, elementary teachers' beliefs promoted and involved the students' achievements and their positive outcomes, students developed their emotional and social development and trusting relationship with their teachers (Olgan, 2017). The study argued that the achievement of students and self-efficacy of elementary teachers and motivation have positive relationships, elementary teacher's self-efficacy attitude, commitment, and activities also effected on the practices in the management of the classroom. High self-efficacy teachers' academic beliefs showed their subsequent teaching behaviors, classroom practices, lesson planning, and instructional decision in classrooms (Dasta, 2016). The engagement of instructions and classroom management also assessed by the self-efficacy of teachers to develop student's achievements and teachers' skills and abilities 
enhanced the students learning (Hasselhorn, 2017). The high self-efficacy elementary teachers more willing to worked and manage the classroom, teachers are implementing the new activities in the curriculum, its concerns, and increasing the performances of the students in learning (Gudek, 2019).

\section{Student's Perception towards Teacher's Self-efficacy}

Students have positive behavior and take interested in their study because teachers have high selfefficacy beliefs, low self-efficacy teachers' beliefs have lacked the initiative or motivation behavior so that the students leave the study or more weak $\mathrm{n}$ their learning. This study suggested that students are not maintained the classroom discipline and not explore potential antecedents of students when teachers are low self-efficacy beliefs (Christophersen, 2017). Teacher's positive and their beliefs effected on the character of students and moral development, positive self-efficacy beliefs teachers have qualities such as honest, comparative, and hard-working to work with students (Sar1, 2017). Student's outcomes and achievements from the learning are associated with the teacher's efficacy and their effort and worked shown the students strong sense planning and organization (Demirel, 2017).

\section{The Objectives of the Study}

1. To investigate the self-efficacy of elementary teachers and attitude towards their practices in classroom management

2. To find out students' perceptions about self-efficacy of elementary teachers' practices in the classroom management.

3. To investigate the gender difference between male and female elementary teachers' selfefficacy towards practices their classroom management

\section{Methodology}

All elementary schools (186) male and female, all elementary (1063) male and female elementary school teachers and all elementary students (40228) were selected for the population of the study. The respondents selected by the use of the technique of multistage sampling; first stage 32 elementary schools' random sample were selected, 36 male and 26 female schools stratified random sample was selected. In the third stage, ten elementary students were randomly selected from each school, and a total of 180 male elementary 130 female elementary teachers were selected as the sample from the population. The survey method questionnaire was developed from the researcher to investigate the elementary self-efficacy and their attitude towards practices in the classroom management.

\section{Results and Finding}

The results of the study consisted of the elementary teacher's self-efficacy and their attitude towards their practices of classroom management. The results are based on the following objectives.

\section{Objective 01}

To explore the self-efficacy elementary teachers' attitude towards their practices in classroom management

\section{Table 01}

Elementary teachers' self-efficacy towards their practices in classroom management

\begin{tabular}{|c|c|c|c|c|c|c|c|c|}
\hline \multirow[t]{2}{*}{ S.No. } & \multirow[t]{2}{*}{ Statement } & \multicolumn{5}{|c|}{ Response frequency } & \multirow[t]{2}{*}{$\mathbf{X}^{2}$} & \multirow[t]{2}{*}{$\mathbf{P}$} \\
\hline & & $\mathbf{A}$ & $\mathbf{O}$ & $\mathbf{S}$ & $\mathbf{R}$ & $\mathbf{N}$ & & \\
\hline \multirow[t]{2}{*}{1} & \multirow{2}{*}{$\begin{array}{l}\text { Keep friendly environment in the } \\
\text { classroom }\end{array}$} & 19 & 42 & 2 & 0 & 0 & \multirow[t]{2}{*}{40.872} & \multirow[t]{2}{*}{.000} \\
\hline & & $31 \%$ & $67 \%$ & $2 \%$ & $0 \%$ & $0 \%$ & & \\
\hline \multirow[t]{2}{*}{2} & \multirow{2}{*}{ Interruption is no during class } & 13 & 45 & 04 & 0 & 0 & \multirow[t]{2}{*}{44.934} & \multirow[t]{2}{*}{.000} \\
\hline & & $21 \%$ & $73 \%$ & $6 \%$ & $0 \%$ & $0 \%$ & & \\
\hline \multirow[t]{2}{*}{3} & \multirow{2}{*}{$\begin{array}{l}\text { Have ability change the attitude of } \\
\text { student in different situation }\end{array}$} & 13 & 41 & 08 & 0 & 0 & \multirow[t]{2}{*}{30.614} & \multirow[t]{2}{*}{.000} \\
\hline & & $21 \%$ & $66 \%$ & $13 \%$ & $0 \%$ & $0 \%$ & & \\
\hline \multirow[t]{2}{*}{4} & Made good relationship with & 42 & 18 & 02 & 0 & 0 & \multirow[t]{2}{*}{39.228} & \multirow[t]{2}{*}{.000} \\
\hline & students & $68 \%$ & $29 \%$ & $03 \%$ & $0 \%$ & $0 \%$ & & \\
\hline \multirow[t]{2}{*}{5} & Time managed in the classroom & 29 & 30 & 03 & 0 & 0 & \multirow[t]{2}{*}{22.679} & \multirow[t]{2}{*}{.000} \\
\hline & & $47 \%$ & $48 \%$ & $05 \%$ & $0 \%$ & $0 \%$ & & \\
\hline \multirow[t]{2}{*}{6} & Lesson planning is attentive for & 24 & 35 & 03 & 0 & 0 & \multirow[t]{2}{*}{26.581} & \multirow[t]{2}{*}{.000} \\
\hline & students & $39 \%$ & $56 \%$ & $05 \%$ & $0 \%$ & $0 \%$ & & \\
\hline \multirow[t]{2}{*}{7} & Create interested environment for & 16 & 35 & 06 & 0 & 0 & \multirow[t]{2}{*}{30.00} & \multirow[t]{2}{*}{.000} \\
\hline & student attention & $26 \%$ & $56 \%$ & $09 \%$ & $0 \%$ & $0 \%$ & & \\
\hline \multirow[t]{2}{*}{8} & Students have Equal opportunities & 29 & 32 & 05 & 0 & 0 & \multirow[t]{2}{*}{29.329} & \multirow[t]{2}{*}{.000} \\
\hline & for asking question & $46 \%$ & $52 \%$ & $08 \%$ & $0 \%$ & $0 \%$ & & \\
\hline 9 & Motivated students to participants & 24 & 33 & 02 & 0 & 0 & 20.001 & .000 \\
\hline
\end{tabular}




\begin{tabular}{lllllllll}
\hline \multirow{2}{*}{10} & & $38 \%$ & $53 \%$ & $03 \%$ & $0 \%$ & $0 \%$ & & \\
& Lesson planning with pleasant & 19 & 39 & 04 & 0 & 0 & 29.839 & .000 \\
& behavior & $31 \%$ & $63 \%$ & $06 \%$ & $0 \%$ & $0 \%$ & & \\
\hline
\end{tabular}

The table shows that the teachers' respondents $(67 \%)$ were often likely to have a friendly classroom environment and the response show $\left(\mathrm{x}^{2}=40.872, \mathrm{p}=.000\right)$ significant of the study. The $73 \%$ of respondents said there is no interruption in their classroom management and the significance response was $\left(\mathrm{x}^{2}=44.934, \mathrm{p}=.000\right)$ at 0.05 . The response was significant, and $66 \%$ of elementary teachers were often likely to have the ability to change the student attitude according to the situation. The 68 elementary teachers were often like to make good relationships with students and $47 \%$ of elementary teachers were often like to easily manage time during the class. The $56 \%$ of respondents often like to make attentive lesson plans for elementary students and $\left(\mathrm{x}^{2}=25.581, \mathrm{p}=.000\right)$ significant of the study. The $65 \%$ of elementary teachers created an interesting environment for student attention during class and the significance response was $\left(\mathrm{x}^{2}=22.548, \mathrm{p}=.000\right)$ at 0.05 . The respondents show that $52 \%$ of teachers often like to give all students opportunities for asking questions in the classroom. $53 \%$ of elementary teachers motivated students to take participate in the classroom activities and the value of $\left(x^{2}=20.001, p=.000\right)$ at 0.05 shows the significance of the study. The $63 \%$ of elementary school teachers were often like to lesson planning in the pleasant attitude for students and $\left(x^{2}=29.839\right.$, $\mathrm{p}=.000$ ) at 0.05 shows the significance of the study. This table shows that high self-efficacy elementary teachers great works and doing well practices of classroom management. The table shows teachers are highly motivated

Objective no 02

To find out students' perceptions about elementary teachers' practices in classroom management.

Table 02

Students' perceptions about self-efficacy elementary teachers' practices in the classroom management

\begin{tabular}{|c|c|c|c|c|c|c|c|}
\hline \multirow[t]{2}{*}{ S.No. } & \multirow[t]{2}{*}{ Statement } & \multicolumn{5}{|c|}{ Response frequency } & \multirow[t]{2}{*}{ Mean } \\
\hline & & A & $\mathbf{O}$ & $\mathbf{S}$ & $\mathbf{R}$ & $\mathbf{N}$ & \\
\hline \multirow[t]{3}{*}{1} & \multirow{3}{*}{$\begin{array}{l}\text { The friendly environment created in } \\
\text { my class }\end{array}$} & 08 & 38 & 16 & 0 & 0 & \multirow[t]{3}{*}{3.88} \\
\hline & & 13 & $61 \%$ & $26 \%$ & $0 \%$ & $0 \%$ & \\
\hline & & $31 \%$ & & & & & \\
\hline \multirow[t]{2}{*}{2} & \multirow{2}{*}{$\begin{array}{l}\text { Free interruption in the classroom } \\
\text { activities }\end{array}$} & 07 & 43 & 12 & 0 & 0 & \multirow[t]{2}{*}{3.92} \\
\hline & & $11 \%$ & $69 \%$ & $19 \%$ & $0 \%$ & $0 \%$ & \\
\hline \multirow[t]{2}{*}{3} & \multirow{2}{*}{$\begin{array}{l}\text { Teachers motivated to change attitude } \\
\text { in learning situations }\end{array}$} & 06 & 38 & 18 & 0 & 0 & \multirow[t]{2}{*}{3.82} \\
\hline & & $10 \%$ & $61 \%$ & $29 \%$ & $0 \%$ & $0 \%$ & \\
\hline \multirow[t]{2}{*}{4} & Friendly environment in the & 0 & 42 & 20 & 0 & 0 & \multirow[t]{2}{*}{4.06} \\
\hline & classroom & $0 \%$ & $68 \%$ & $32 \%$ & $0 \%$ & $0 \%$ & \\
\hline \multirow[t]{2}{*}{5} & Easily managed and maintain & 29 & 27 & 14 & 02 & 0 & \multirow[t]{2}{*}{4.04} \\
\hline & classroom & $32 \%$ & $43 \%$ & $22 \%$ & $03 \%$ & $0 \%$ & \\
\hline \multirow[t]{2}{*}{6} & Students are attentive from lesson & 25 & 25 & 17 & 02 & 0 & \multirow[t]{2}{*}{3.96} \\
\hline & planning & $30 \%$ & $40 \%$ & $27 \%$ & $03 \%$ & $0 \%$ & \\
\hline \multirow[t]{2}{*}{7} & Students take attention in the & 08 & 35 & 19 & 0 & 0 & \multirow[t]{2}{*}{3.85} \\
\hline & classroom & $13 \%$ & $56 \%$ & $31 \%$ & $0 \%$ & $0 \%$ & \\
\hline \multirow[t]{2}{*}{8} & Students are excited in the classroom & 16 & 32 & 12 & 02 & 0 & \multirow[t]{2}{*}{3.80} \\
\hline & activities & $26 \%$ & $52 \%$ & $19 \%$ & $03 \%$ & $0 \%$ & \\
\hline \multirow[t]{2}{*}{9} & Motivated by teachers' attentions & 0 & 40 & 16 & 06 & 0 & \multirow[t]{2}{*}{3.58} \\
\hline & & $0 \%$ & $65 \%$ & $26 \%$ & $08 \%$ & $0 \%$ & \\
\hline \multirow[t]{2}{*}{10} & Feel happy to work with teachers & 03 & 40 & 17 & 02 & 0 & \multirow[t]{2}{*}{3.70} \\
\hline & & $05 \%$ & $65 \%$ & $27 \%$ & $03 \%$ & $0 \%$ & \\
\hline
\end{tabular}

The Table illustrated that elementary student's perception of self-efficacy of elementary teacher's practices in classroom management is high level. The elementary teacher's self-efficacy is high level, the mean score (4.96 to 3.58) shows the high-level self-efficacy elementary teachers' attitude towards practices of classroom management. The mean (3.88) respondents are happy to work with a friendly teacher's environment created by the elementary teachers at a high level. The mean (3.92) students' interruption is freely in the classroom at a high level. The respondent's show (Mean 3.82) self-efficacy elementary teachers motivated to students change their attitude during different learning situations at a high level. The respondents are highly motivated by the classroom environment (M 4.06), the mean (4.04) shows that management and maintains the classroom at a high 
level. The respondents (M 3.96) are attentive in the practices of self-efficacy elementary teachers' classrooms at a high level. The elementary students (M 3.85) take more attention in the self-efficacy elementary teachers practice in the classroom management. The elementary students (M 3.80) are excited in the participant of the classroom at a high level, the respondents (M 3.58) are highly motivated in the self-efficacy elementary teachers' classrooms. The respondents (M 3.70) are feeling happy attitude in the self-efficacy practices of the classroom, overall, the elementary student's perception of self-efficacy elementary teachers' practices in classroom management at a high level. The table represented that students feel happy, motivated, attentive in the elementary self-efficacy teacher's classroom.

\section{Objective No 03}

To investigate the gender differences between male and female elementary teachers' self-efficacy towards practices their classroom management

Table 03

The difference between male and female elementary teachers' self-efficacy

\begin{tabular}{lllllll}
\hline S. $\mathbf{N}$ & Gender & N & Mean & Std. Deviation & T & P \\
\hline 1 & Male & 36 & 106.33 & 6.211 & 2.459 & 0.017 \\
2 & Female & 26 & 110.00 & 5.154 & & \\
\hline
\end{tabular}

The table illustrates that mean of female teachers' self-efficacy (106.33) is higher than the male teachers (110.33). This table indicates that there is a significance difference between male and female teachers' self-efficacy of management practices in the classroom at the secondary level of the Hazara division; female teachers 'and management classroom practices are higher than the male teacher in secondary school.

\section{Conclusion, Recommendation}

This study focused on the elementary teachers' self-efficacy attitude towards their practices in the classroom management and elementary students' perception about the self -efficacy teachers' attitudes towards their practices in classroom management. The students' participation support by the strong self-strong efficacy opinions teachers teaching practices, the instruction adjustments failed, and student engagement and participation are poor due to the teachers less self-efficacy

The finding of the study is that high self-efficacy teachers make classroom friendly environment, students' attitude modifies and interruption-free. Most of the participants respond that the nonseriously attitude of the students are making seriously by the high self-efficacy teachers' friendly relation with their students, make lessons plan and time management. The respondent highly responds that high self-efficacy teachers created a highly learning environment in the classroom and students take part with encouragement in the activities and ask questions with confidently. The high selfefficacy teacher's instruction system is strong, during the lesson they remain cool, they do not miss their classes, and encourage and support the confused students. Most of the elementary teachers agreed that students work with teachers with full confidence and solved assignments with a full energetic attitude. In the classroom of high self-efficacy teachers made effective rules, slow learners take extra guidance from the high self-efficacy teachers and creativity activates motivate the students. The high self-efficacy teachers managed the group's activities, effective learning rewards activities, observed and measured the student's performance on giving them different tasks. The finding of the study is that female teachers. The female elementary teachers have a high self-efficacy attitude towards their practices of classroom management than the male elementary teachers. The male elementary teachers are less efficacious in the practices of classroom management then the female elementary teachers. The female self-efficacy elementary teachers are implementation practices of classroom management are better than the male self-efficacy elementary teachers. The low selfefficacy teachers do not manage class properly, not changed the student's careless behavior, and not make the learning environment in the classroom. In the low self-efficacy teacher classroom does not make the effective rule, not creativity activities, not give extra time to slow learner students, and not give extra time to the slow learner. The low efficacy male teachers were not participants in the creative activities, not managed time, and not motivated slow learner students.

\section{Recommendations}

On the base of conclusions, the researcher made the following recommendations to help the teacher and administration analyze the serious evidence about elementary classroom management practices. 
The high self-efficacy teachers have a positive and motivated attitude towards practices of classroom management. So, there is a need to enhance the self-efficacy through training programs and workshops.

$>\quad$ It was found that female teachers' self-efficacy and classroom management practices is greater than male teachers but need to enhance the male teacher's ability to improve teaching methods for implementations of edifying activities through different educational programs.

\section{References}

Abu-Tineh, A. M., Khasawneh, S. A., \& Khalaileh, H. A. (2011). Teacher self-efficacy and classroom management styles in Jordanian schools. Management in Education, 25(4), 175-181.

Andrew, e. (2019). Self-efficacy and instrumental instruments adjudication. self-efficacy. hempsted, New York, USA: ProQuest.

Ansonga, D., Eisensmith, S. R., Okumu, M., \& Chowa, G. A. (2019). The importance of self-efficacy and educational aspirations for academic achievement in resource-limited countries: Evidence from Ghana. Journal of Adolescence, Value and issue is required over here 13-23.

Bakker, D. M. (2016). Fear of Movement and Low Self-Efficacy Are Important Barriers in Physical Activity after Renal Transplantation. Plos, 1-15.

Chang, Y.,S., Chen, M. Y.-C., Chuang, M.-J., \& Chou, C.-h. (2019). Improving creative self-efficacy and performance through computer-aided design application. Thinking Skills and Creativity, 103-111.

Chen, K. W. (2018). Preservice teachers' self-efficacy in managing studentswithsymptomsofattention deficit/hyperactivity disorder: Therolesof diagnosticlabelandstudents' gender. Wiley, 1-13.

Christophersen, E. E.-A. (2017). Perceptions of Digital Competency among Student Teachers: Contributing to the Development of Student Teachers' Instructional Self-Efficacy in TechnologyRich Classrooms. Education Science, 1-15.

Dasta, F. M. (2016). English Teachers' Self-Efficacy Beliefs and Students Learning Approaches: the Role of Classroom Structure Perception. International Journal of Educational Psychology, 305-328.

Demirel, T. O. (2017). An Analysis of Self-efficacy Perceptions of Physical Education and Sport Teacher Candidates and Other Teacher Candidates on Teaching Profession. European Journal of Educational Research, 313-319.

Rashid, K.,, A. A., Khalid, N., \& Salfi, N. A. (2014). Perceptions of Students about Classroom Management as a Contributing Factor Towards Learning at Secondary School. Journal of Education and Human Development, 3(2), 713-728.

Garvis, S., \& Pendergast, D. (2016). Asia-Pacific Perspectives on Teacher Self-Efficacy. Rotterdam, Northland: Sense Publishers.

Gudek, B. (2019). Computer Self-Efficacy Perceptions of Music Teacher Candidates and Their Attitudes towards Digital Technology. European Journal of Educational Research, 683-696.

Hasselhorn, L. H.-H. (2017). Teachers' self-efficacy beliefs regarding the assessment and promotion of school-relevant skills of preschool children. Early Child Development and Care, 339-351.

Lee, K. W., Cheung, R. Y., \& Chen, M. (2019). Preservice teachers' self-efficacy in managing students with symptoms of attention deficit / hyperactivity disorder: The roles of diagnosticlabelandstudents' gender. Wiley Periodicals, 1-13.

Nassir, A. A., \& Yusob, N. H. (2019). Students' Perception of the Use of Code-Switching in Mathematics Classroom: Looking at Gender Differences. Springer, 155-162.

Olgan, N. A. (2017). Pre-service early childhood teachers' self-efficacy beliefs towards parent involvement. Teaching Education, 421-434.

Patterson, T. T., \& Farmer, D. A. (2018). Classroom Management Self-Efficacy of Pre-Service Teachers. World Journal of Educational Research, 5(2), 134-143.

Peleg, O., \& Idan-Biton, M. (2018). Self-efficacy: familial and cultural perspectives. British Journal of Guidance \& Counselling, 1-16.

Qian Gong, K., Wai Ling Yeung, Grace Zhang, \& Toni Dobinson. (2019). Students' Perceptions of the Use of Video Recording in Additional Language Oral Assessments. Springer, 133-155.

Sarı, E. Y. (2017). Teachers' Qualities And Self-Efficacy Perceptions In Character Education. Acta Didactica Napocensia, 35-48.

Szanton, M. D.-R. (2019). High coping self-efficacy associated with lower odds of pre-frailty/frailty in older adults with chronic disease. Aging \& Mental Health, 1-6. 